\title{
Seasonal physicochemical variation in the Nabugabo wetland
}

\author{
James OKOT-OKUMU* \\ Makerere University Institute of Environment \& Natural Resources, P.O. Box.7062 Kampala, Uganda. \\ *Corresponding author; E-mail: jokotokumu@muienr.mak.ac.ug; jokotokumu@yahoo.com \\ Tel: $+256-772411460$
}

\begin{abstract}
The study determined physicochemical characteristics of Lake Nabugabo wetland during a wet and a dry season to evaluate season variation in water quality. Standard (APHA 1992) and HACH methods were used to determine the physicochemical parameters for a period of one seasonal cycle. Results were $\mathrm{pH} 3.8$ (3.0-4.2); temperature $23.0(19.4-26.4){ }^{0} \mathrm{C}$; conductivity $20.5(15.6-30.45) \mu \mathrm{Scm}^{-1}$; total dissolved solids 11.4 (4.1-14.2) $\mathrm{mgl}^{-1}$; dissolved oxygen 3.9(0.0 -5.3) $\mathrm{mgl}^{-1} ; \mathrm{Ca}^{++} 3.0(0.2-4.3) \mathrm{mgl}^{-1} ; \mathrm{Mg}^{++}$2.1(0.06-2.5) $\mathrm{mgl}^{-1} ; \mathrm{K}^{+}$ $0.9(0.8-1.1) \mathrm{mgl}^{-1}$; $\mathrm{Na}^{+} 2.9(2.1-3.2) \mathrm{mgl}^{-1}$; total phosphorus $0.3(0.07-1.3) \mathrm{mgl}^{-1}$; soluble reactive phosphate $0.002(0.004-0.06) \mathrm{mgl}^{-1}$; total nitrogen $0.8(0.5-1.8) \mathrm{mgl}^{-1}$; nitrate-nitrogen $0.01(0.001-0.12) \mathrm{mgl}^{-1}$; ammonianitrogen $0.46(0.1-2.2) \mathrm{mgl}^{-1}$. Nitrate-nitrogen and dissolved oxygen varied significantly $(\mathrm{P}<0.05)$, while phosphorus variation was weak $(\mathrm{P}=0.2)$ and both were higher during the rainy season. Temperature, $\mathrm{pH}$, conductivity and the cations exhibited non-significant $(\mathrm{P}>0.05)$ variation with season. The wetland hydroperiods were 0.83 north of Lake Nabugabo and 0.58 south of the Lake. Seasonal variations of nitrogen and phosphorus concentrations were strongly linked to rainfall and hydroperiods. The study showed that the wetland water quality varies with season which is important for designing temporal sampling strategy and the understanding of wetland influence on adjacent open water bodies.
\end{abstract}

(C) 2010 International Formulae Group. All rights reserved.

Key words: Physicochemical, seasonal variation, Nabugabo wetland.

\section{INTRODUCTION}

The Nabugabo ecosystem has ancient and nutrient poor soils. The soils in this large expanse of lowland area around Lake Nabugabo are leached of ions and nutrients. The wetland bordering Lake Nabugabo has a unique assemblage of flora such as Sphagnum moss, Drosera sp., and Utricularia sp., which are a rare occurrence in this region and at this altitude. The dominant grass species in the wetland is Loudetia phragmitoides (A. Peter) C.E. Hubbard that covers the outward wider parts of the wetland followed by Miscanthidium violaceum (K. Schum) Robyns close to the lake (Chapman et al., 1996; OkotOkumu, 2004). According to Okot-Okumu (2004), Loudetia phragmitoides is a major nutrient source for the wetland and open lake system.

Lake Nabugabo is surrounded by a wetland except for a small portion to the west and northwest of the lake. It would therefore imply that this wetland has a big influence on the open lake. Major hydrological inputs into this wetland are rainfall and groundwater. The hydrological connections between the wetland and Lake Nabugabo are the Juma River and channels that perforate the wetland interior 
from the lake. These wetland channels are either natural or manmade (by fishermen) as reported by Beadle and Lind (1960).

Several studies have demonstrated wetlands as important ecosystems for nutrient cycling (Duff et al., 2009; Fennessy et al., 2008; Parray et al., 2010; Siraj et al., 2010) and also explained their importance in controlling nutrient availability to lakes (Duff et al., 2009; Mitsch and Gossenlink, 2007; Poulin et al., 2009).

The dominant vegetation of Loudetia phragmitoides and Miscanthidium violaceum die off during the dry season and young ones sprout during the first rain maturing and flowering during one cycle of dry and wet season of a year. The dead and dry plant materials drop onto wetland water pools and floor during the dry seasons. During rainy seasons the wetland floods submerging the dead vegetation creating suitable conditions for decomposition and nutrient recycling in the wetland. Saturated wetland soils and debris decompose slowly and these constitute long-term nutrient storage compartments. Seasonal change that cause dry conditions shifts the redox status resulting in oxidation of complex organic compounds into soluble compounds including organic acids, NH4+,NO3- and soluble reactive Phosphorus (Mitsch and Gossenlink, 2007). The subsequent re-wetting during rainy season ultimately affects nutrient cycling and nutrient status of adjacent receiving waters (Duff et al., 2009; Poulin et al., 2009).

The Nabugabo wetland therefore provides a good place to study how seasonal events (rain and hydrological variation) can influence physico-chemical characteristics of a relatively small tropical wetland. Being in a highly leached catchment this wetland would be important to the adjacent Lake ecosystem for minerals and nutrients. Seasonal events like rainfall and flooding are known to influence nutrient and mineral concentrations in the environment promoting recycling and also in some cases by either dilution or inputs (Agbaire and Obi, 2009; Duff et al., 2009; Poulin et al., 2009).
The Nabugabo wetland has already received international recognition by it being declared a Ramsar site in 2004, but no studies have yet been done, except on fish ecology (Chapman and Chapman, 1996; Chapman et al., 1996, Kaufman et al., 1997). There are no publications on the physico-chemical characteristics of the Nabugabo wetland. This study therefore assessed water physicchemical characteristics of the Nabugabo wetland and the effect of wet and dry season parameters.

\section{MATERIALS AND METHODS}

The study area is a grass wetland around a small satellite lake (Lake Nabugabo) in south-western Uganda $\left(0^{\circ} 20^{\prime} \mathrm{S}\right.$ $\left.0^{\circ} 23^{\prime} \mathrm{S} / 31053^{\prime} \mathrm{E}-31057^{\prime} \mathrm{E}\right)$, about $5 \mathrm{~km}$ to the west of Lake Victoria (Fig. 1). The wetland grasses Loudetia phragmitoides (A. Peter) C.E. Hubbard and Miscanthidium violaceum (K. Schum) Robyns are the dominant emergent macrophyte species in the wetland. The climate of the Nabugabo area is equatorial with wet and dry seasons in a year.

Water samples were collected from the wetland to cover at least one wet and one dry period of a year for a maximum of 17 months. Sample locations were A-J displayed in Fig.1.

Conductivity, dissolved oxygen (DO), $\mathrm{pH}$ and water temperature were measured in situ using field meters with appropriate probes according to the manufacturer's instruction. Cations $\left(\mathrm{Ca}^{++}, \mathrm{Mg}^{++}, \mathrm{K}^{+}\right.$, and $\left.\mathrm{Na}^{+}\right)$were determined with Hach 2000 meter using readymade reagents. Other variables total phosphorus (TP), orthophosphate (as soluble reactive phosphate - SRP), total nitrogen $(\mathrm{TN})$, nitrate-nitrogen $\left(\mathrm{NO}_{3}^{-}-\mathrm{N}\right)$, ammoniumnitrogen $\left(\mathrm{NH}_{4}-\mathrm{N}\right)$ were determined according to APHA, (1992). Wetland water level fluctuation was measured at selected locations with a graduated stake driven into the substratum. Hydroperiod was calculated as fraction of the year the wetland flooded. Rainfall and evaporation data was obtained from the Metrological Department in Kampala. Statistical analysis was performed on a variety of parameters comparing wet 
versus dry season (t-test) and correlation analysis was performed on environmental parameters and seasonal variables. In all cases, Minitab Plus ${ }^{\mathrm{TM}}$ was used.

\section{RESULTS}

Rainfall (974.6-1108.2mm) pattern showed distinct wet and dry periods (Fig. 2a). Moisture balance was negative between June and September dry period (Fig. 2b). North of Lake Nabugabo wetland hydroperiod was 10 months flood (0.83) with distinct crests and south of the lake was 7 months flood (0.58) with no crests (Fig. 3). Water levels in the wetland east of Lake Nabugabo were below the surface ( 0.0 hydroperiod) throughout the year (Fig. 3).

The determined physicochemical parameters of the wetland were temperature 23.0 (19.4 - 26.4) ${ }^{0} \mathrm{C} ; \mathrm{pH} 3.8$ (3.0-4.2); conductivity $20.5(15.6-30.45) \mu \mathrm{Scm}^{-1}$; total dissolved solids $11.4 \quad(4.1-14.2) \mathrm{mgl}^{-1}$; dissolved oxygen $3.9(0.0-5.3) \mathrm{mgl}^{-1} ; \mathrm{Ca}^{++} 3.0$
(0.2-4.3) $\mathrm{mgl}^{-1} ; \mathrm{Mg}^{++} 2.1(0.06-2.5) \mathrm{mgl}^{-1} ; \mathrm{K}^{+}$ 0.9 (0.8-1.1) $\mathrm{mgl}^{-1} ; \mathrm{Na}^{+} 2.9$ (2.1-3.2) $\mathrm{mgl}^{-1}$; total phosphorus $0.3(0.07-1.3) \mathrm{mgl}^{-1}$; soluble reactive phosphate $0.002(0.004-0.06) \mathrm{mgl}^{-1}$; total nitrogen $0.8(0.5-1.8) \mathrm{mgl}^{-1}$; nitratenitrogen 0.01 (0.001-0.12) $\mathrm{mgl}^{-1}$; ammonianitrogen $0.46(0.1-2.2) \mathrm{mgl}^{-1}$.

Temperature, $\mathrm{pH}$ and conductivity did not vary significantly $(\mathrm{P}>0.05)$ with season (Fig.4a, 4b and 4c) and all of them exhibited peak values during the dry season. Dissolved oxygen was generally low and varied significantly $(\mathrm{P}<0.05)$ with season peaking during the rainy periods (Fig. $4 \mathrm{~d}$ ).

Nitrogen $\left(\mathrm{NO}_{3}^{-}-\mathrm{N}\right)$ concentration varied very significantly with season $(\mathrm{P}=0.01)$ peaking during the March to May heavy rains (Fig. 5a).

Phosphorus $\left(\mathrm{PO}_{4}^{3-}\right)$ did not vary significantly $(\mathrm{P}>0.05)$ with season (Fig. 5b) peaking in April, May and October rainy periods. Cations did not vary significantly $(\mathrm{P}>0.05)$ with season.

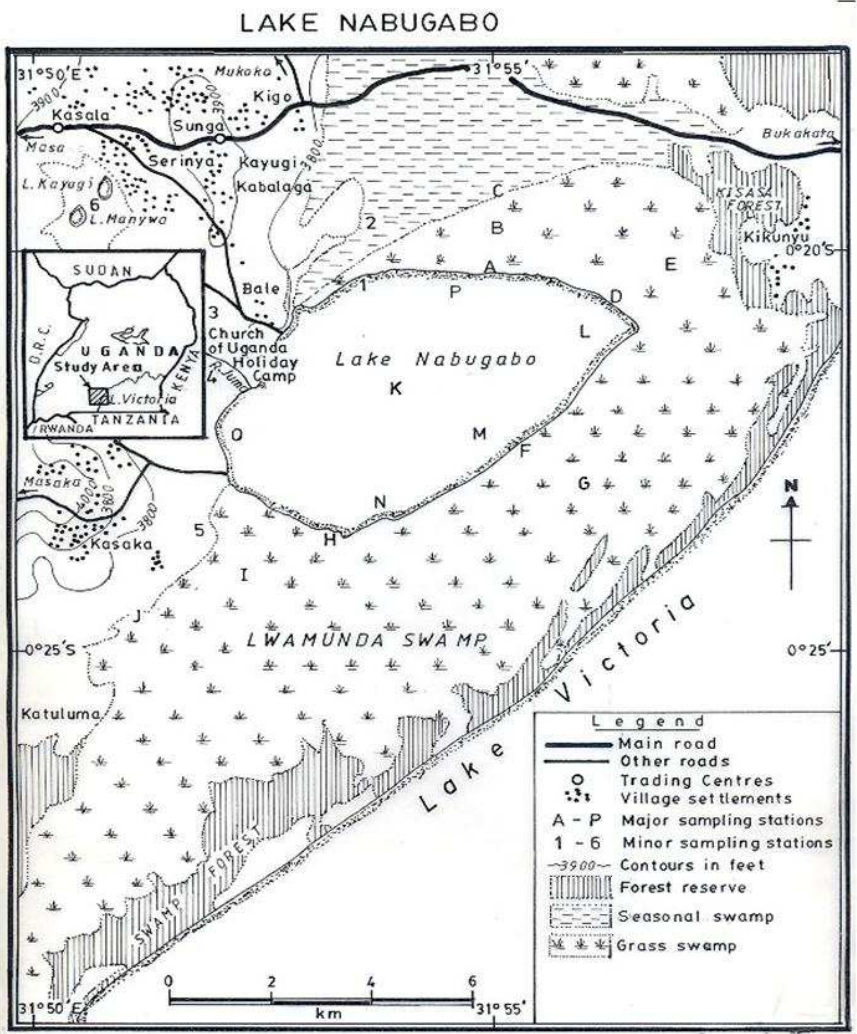

Figure 1: Map of the study area where stations A to $\mathrm{J}$ in the Nabugabo wetland were investigated. 


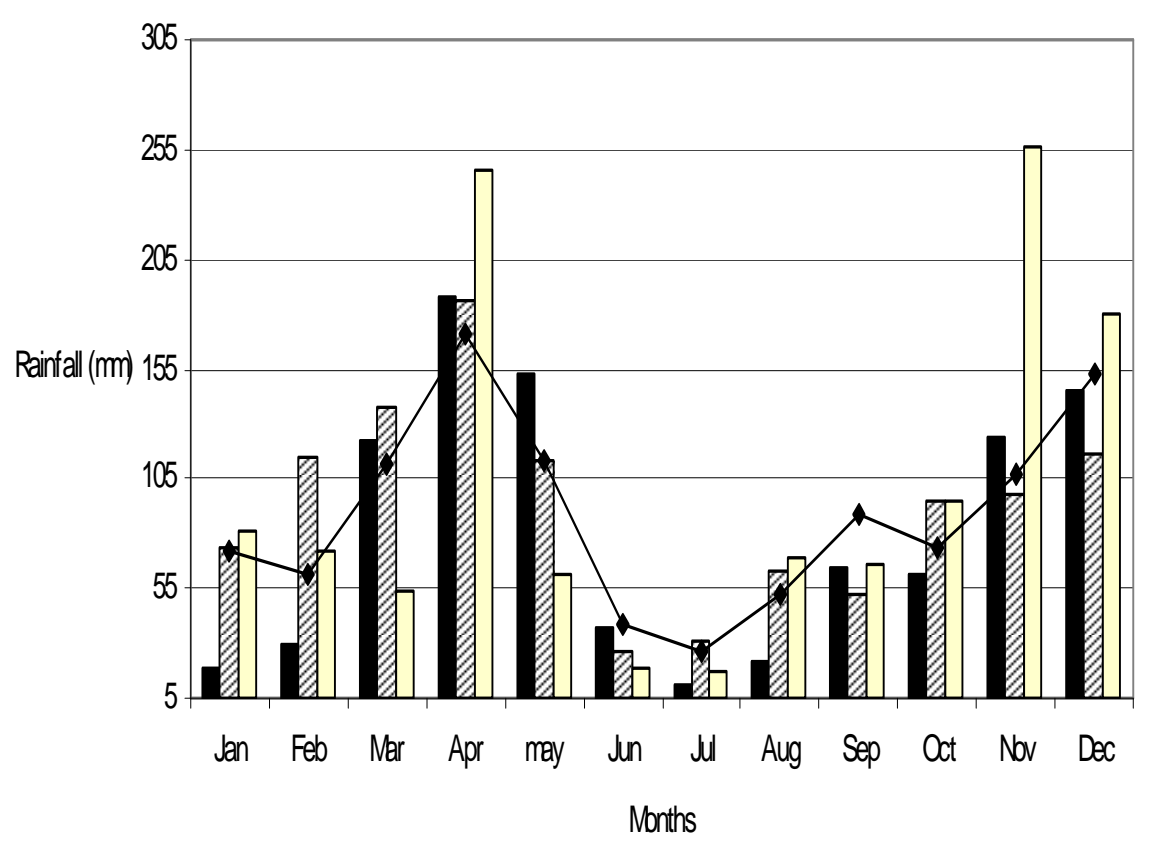

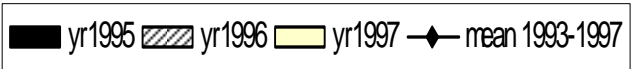

(a)

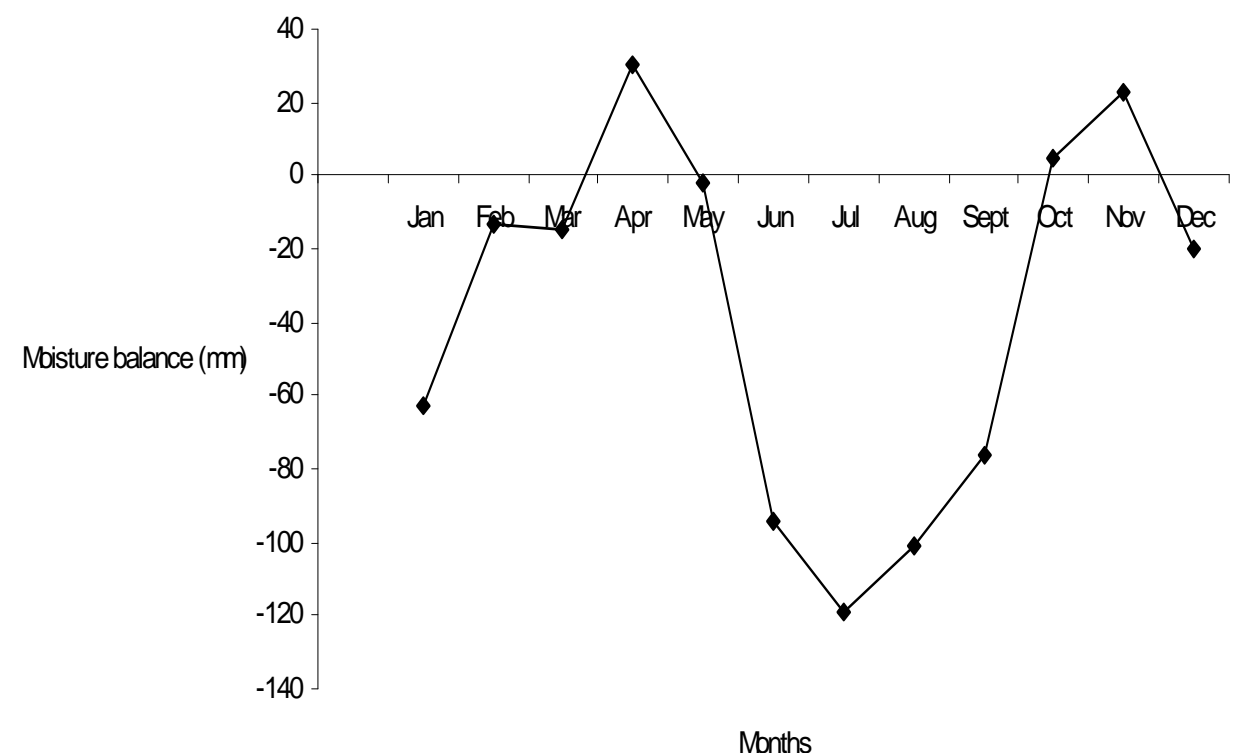

(b)

Figure 2: (a) Yearly rainfall and (b) moisture balance in the Nabugabo study area. 


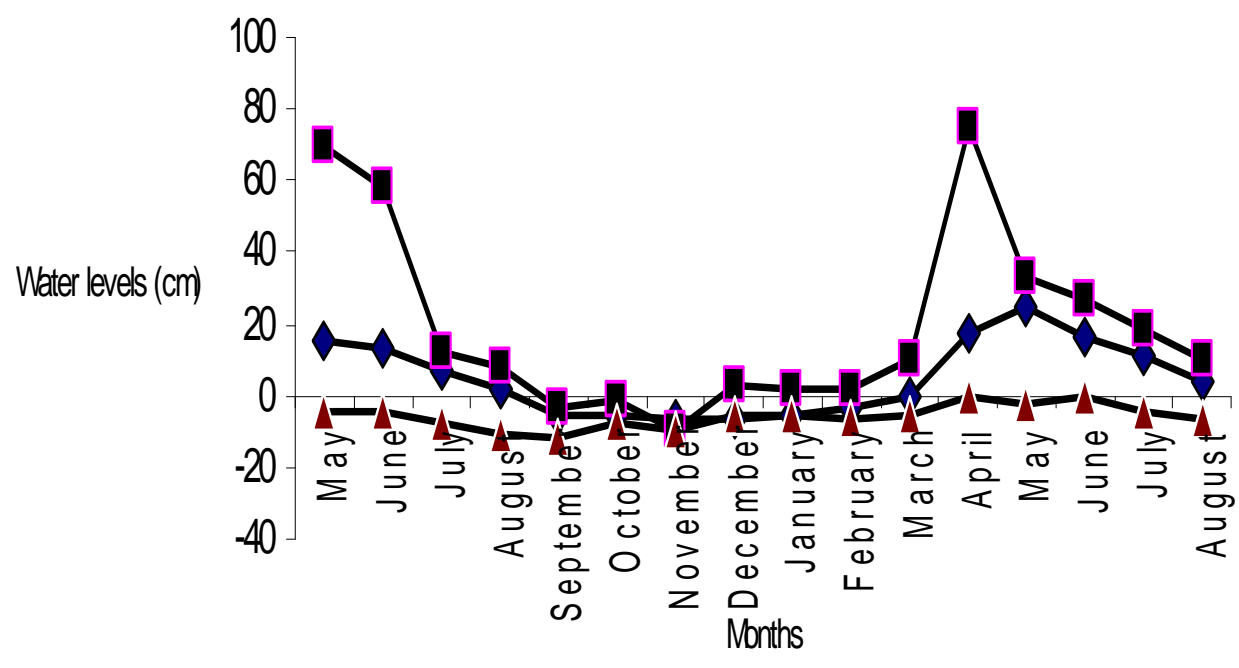

$$
\rightarrow \text { South } \rightarrow-N \text { brth }- \text {-East }
$$

Figure 3: Wetland hydrographs south, north and east of Lake Nabugabo.

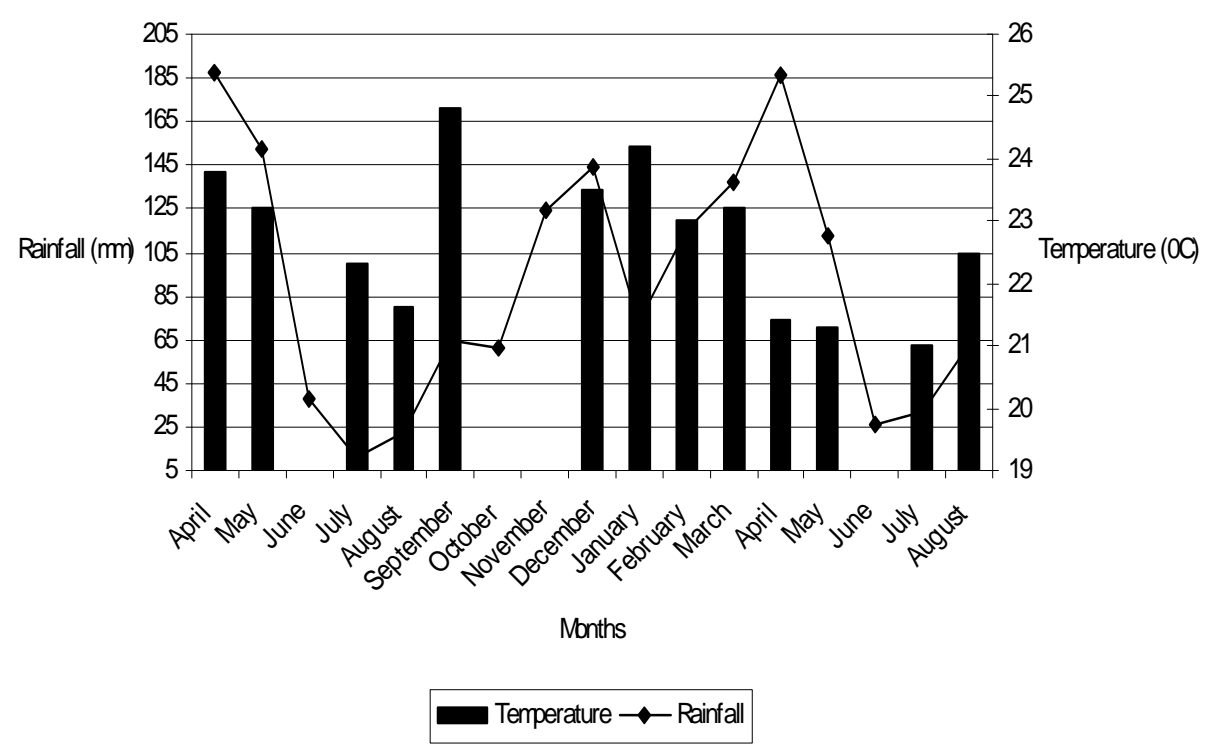

(a) 


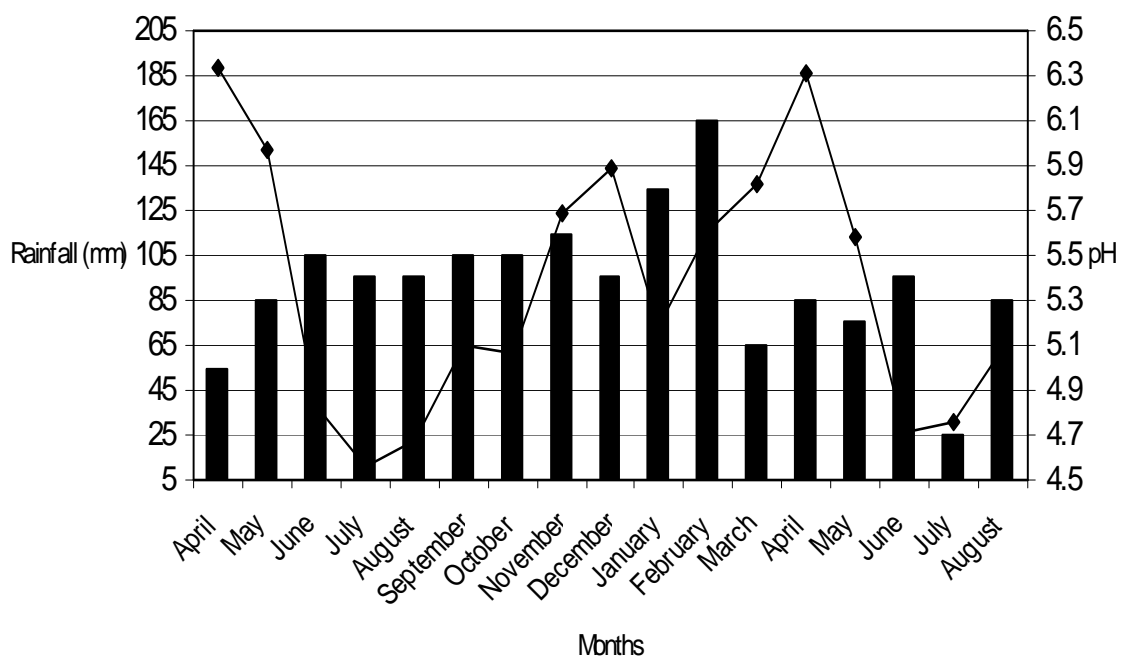

$\longrightarrow \mathrm{pH} \rightarrow$ Rainfall

(b)

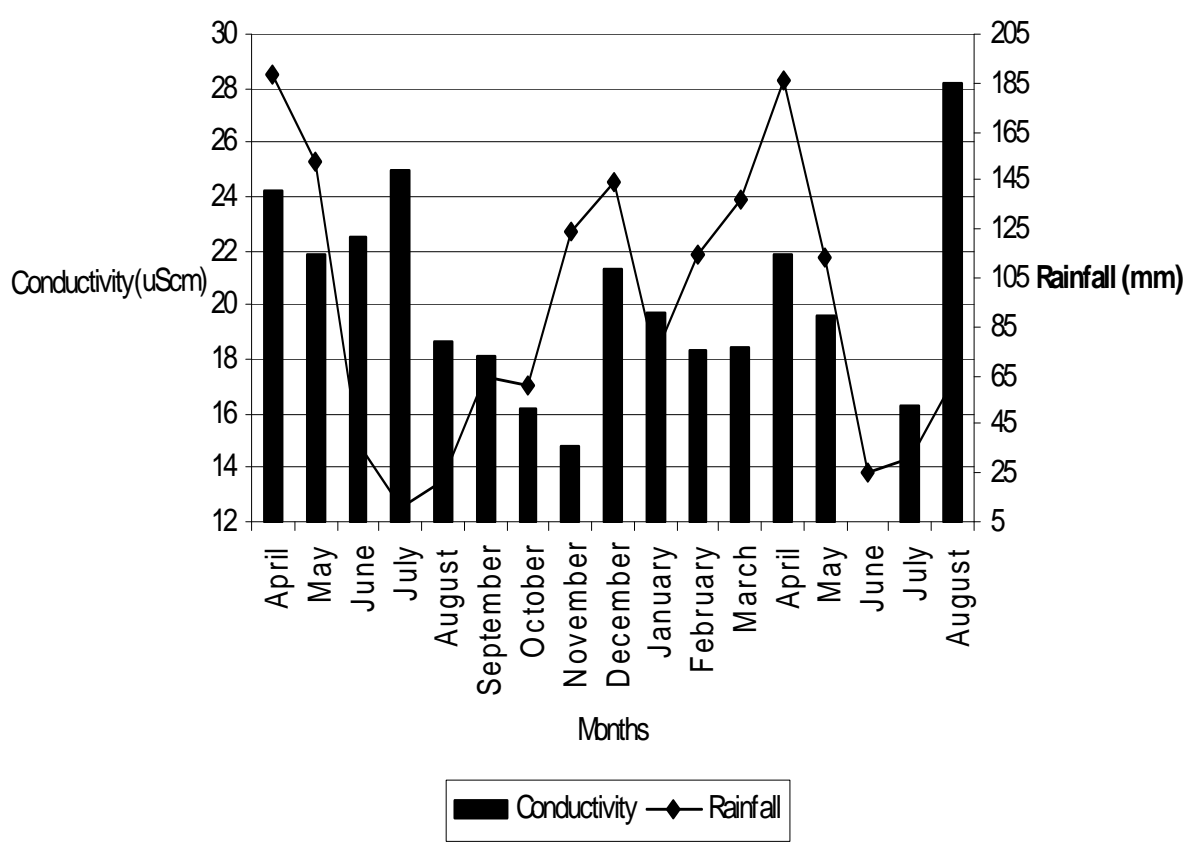

(c) 

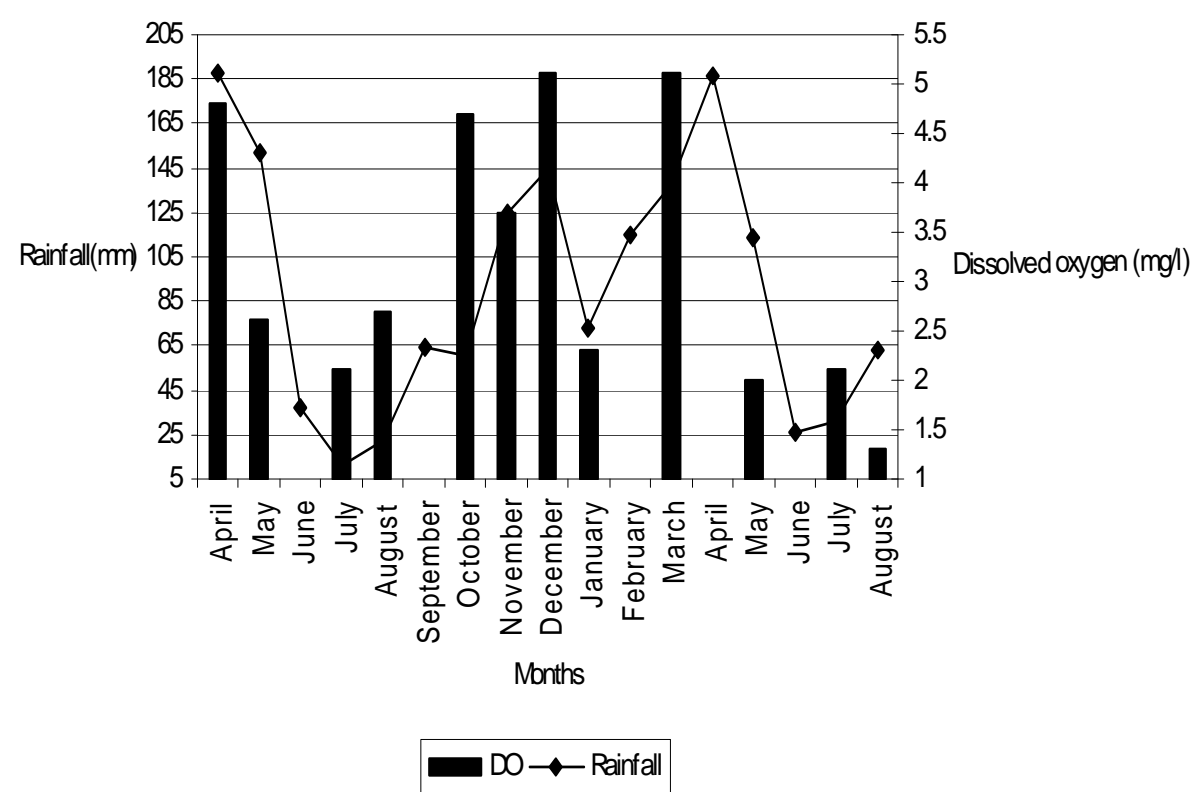

(d)

Figure 4: Seasonal variation of (a) temperature, (b) $\mathrm{pH}$, (c) conductivity and (d) dissolved oxygen in the Nabugabo wetland.

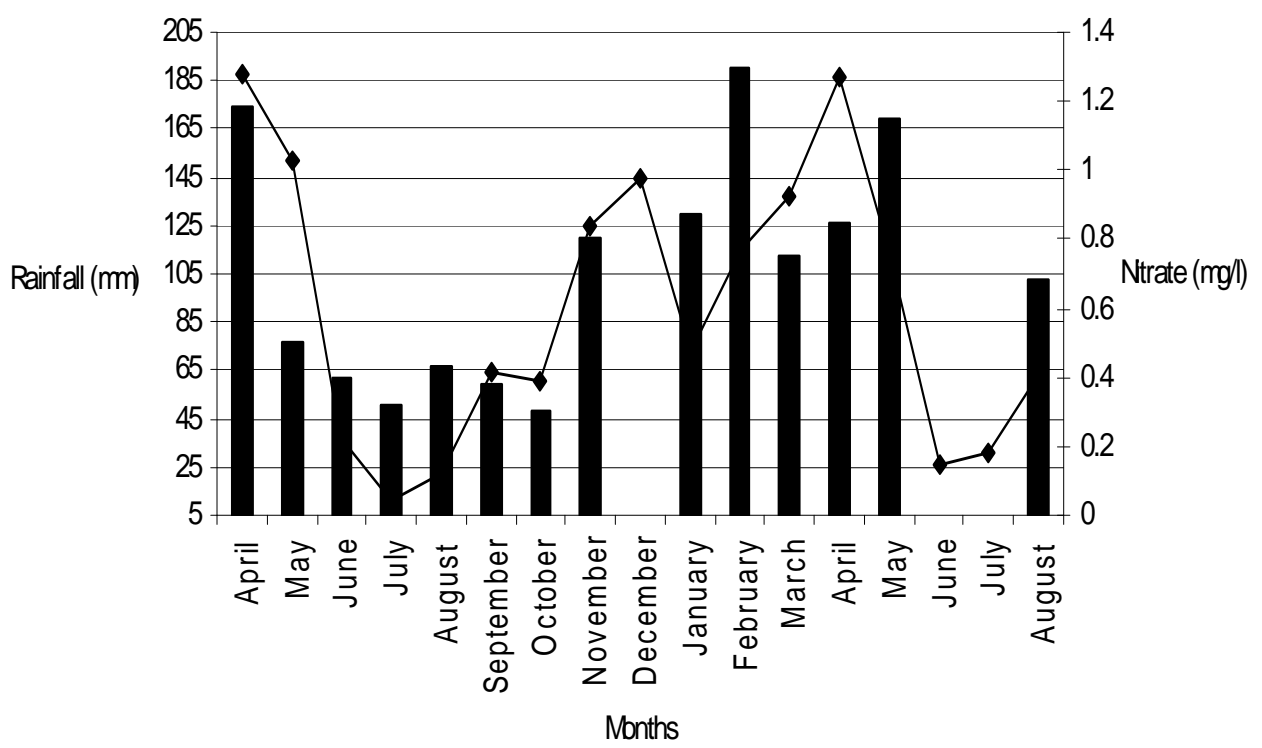

NOB $\rightarrow$ - Rainfall

(a) 


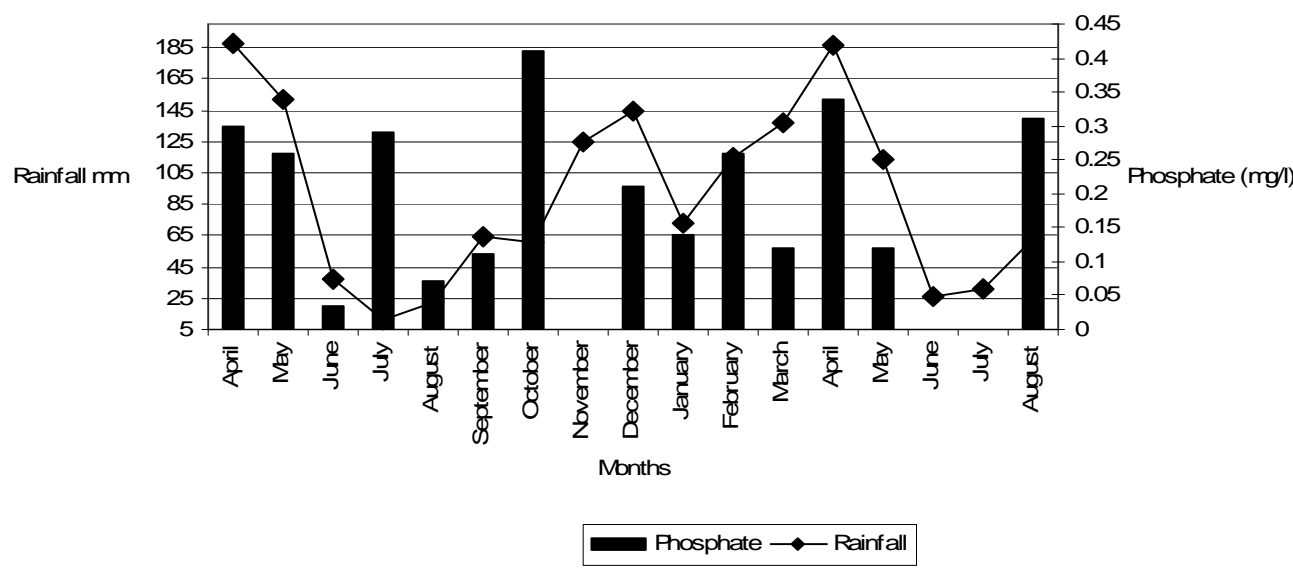

(b)

Figure 5: Seasonal variation of nutrients (a) nitrate and (b) phosphate in the Nabugabo wetland.

\section{DISCUSSION}

The wetland hydrographs displayed distinct response to the annual rainfall and moisture balance cycles. According to Deuver (1988), the variation in the shapes hydrographs can be attributed to the different catchment sizes of the different wetland locations. The catchment size influences hydrological response to inputs such as rainfall (Eaton and Yi, 2009). The hydrographs (Fig. 3) responded well to the wetlands different catchment areas displaying different hydroperiod and hydrograph shapes. Other hydrological factors like tides, water depth and slope also influence hydroperiod and shape of the hydrograph (Eaton and Yi, 2009). The shape of hydrographs suggests that water in the Nabugabo system drains over a broad front from the west to the east towards Lake Victoria and this is supported by the topographic gradient. Water cycle is important for nutrient and mineral cycling in the wetland by creating the wet and dry cycles (Duff et al., 2009; Fennessy et al., 2008; Poulin et al., 2009).

Temperature did not vary significantly between the wet and dry seasons due to the wetland vegetation shading of the wetland water. The recoded water temperature range is typical of the Lake Victoria basin wetlands
(Kipkemboi et al., 2002) with a narrow range. Water $\mathrm{pH}$ was acidic typical of freshwater wetlands (Beadle and Lind, 1960; Chapman and Chapman, 1996; Kipkemboi, et al., 2002; Parray et al., 2010) that is attributed to litter decomposition processes that release organic acids under anaerobic conditions experienced in the wetland(Mitsch and Gossenlink, 2007; Reddy and DeLaune, 2008). Acidification of wetlands water can also be attributed to the Sphagnum moss in the wetland area east of Lake Nabugabo that enhance water acidification through ion exchange whereby hydrogen ions are released by the plants in exchange for especially divalent and trivalent cations (Mitsch and Gossenlink, 2007; Reddy and DeLaune, 2008). This puts pressure on the cation poor Nabugabo ecosystem as indicated by the low water conductivity. The scarcity and stunted growth of papyrus in much of the Nabugabo wetlands is attributed to the very low pH (Denny, 1987), while Loudetia phragmitoides (A. Peter) C.E. Hubbard and Miscanthidium violaceum (K. Schum) Robyns have adapted themselves well to this low $\mathrm{pH}$ and low minerals ecosystem. The variation of $\mathrm{pH}$ was not significant between seasons can and can be attributed to the lack of influence of the neutral $\mathrm{pH}$ rainfall in this area. Also ground water that seeps into the wetland had 
acid $\mathrm{pH}$ similar to the wetland $\mathrm{pH}$ and therefore would not alter the wetland $\mathrm{pH}$.

Water conductivity was very low compared to other wetlands in the region (Kipkemboi et al., 2002; Mtui and Nakamura, 2006) and this is attributed to the highly leached Nabugabo catchment that is poor in minerals. The insignificant variation of conductivity and cations with season may be attributed to the minerals (ionic species) being locked up in the wetland vegetation and substratum organic matter and only retuned to water very slowly by the slow decomposition and desorption processes and therefore would exhibit slow response to drivers like rainfall and hydroperiod.

Rainfall (conductivity: $6.9-29.6 \mu \mathrm{Scm}^{-1}$; pH 5.4-7.01; TN 0.58-2.5 $\mathrm{mgl}^{-1}$; TP 0.032$0.63 \mathrm{mgl}^{-1}$ ) and groundwater (conductivity: $14.9 \mu \mathrm{Scm}^{-1}$; $\mathrm{pH}$ 5.0-6.01; orthophosphate $0.016 \mathrm{mgl}^{-1}$; nitrate $0.05 \mathrm{mgl}^{-1}$ ) were low in mineral concentrations that were similar to the wetland water and therefore had no significant influence on the wetland physicochemical properties. According to Okot-Okumu (2004), during litter decomposition, the initial cation leaching process at the onset of the rains is short-lived followed by slow decomposition release that does not reflect the magnitude of wetland inundation levels. This means the response of cations to hydroperiods would be weak.

The irregular peaks displayed by conductivity and $\mathrm{pH}$ were not clearly in response to seasonal rainfall. This may be due to a combination of factors such as leaching, ion exchange and decomposition processes that are influenced by other complex biotic and abiotic environmental factors like peat and organic matter ion uptake, adsorption, immobilisation that influence the $\mathrm{pH}$ and ions in water (Mitch and Gossenlinks, 2007; Reddy and DeLaune, 2008).

Dissolved oxygen (DO) was consistently low as is of other wetlands (Duff et al., 2009; Kipkemboi, et al., 2002; Siraj et al., 2010). The low DO can be attributed to decomposition processes that take up oxygen in the water and the compact nature of the substratum and wind shield provided by wetland vegetation minimising air-water oxygen exchange. Higher dissolved oxygen levels during the rainy seasons can be attributed to the input of aerated rain water. The generally low dissolved oxygen is important in maintaining a unique flora and fauna that is important factor in maintaining the ecology of the Nabugabo ecosystem (Chapman and Chapman, 1996).

Nitrogen concentration peaked during the rainy seasons and it can be attributed to elevated litter decomposition and aeration of the water during the rains. Litter decomposition is known to be influence by rainfall and as a major source of nutrients in wetlands ((Duff et al., 2009; Fennessy et al., 2008; Poulin et al., 2009). The strong positive correlation $(\mathrm{r}=0.64, \mathrm{p}=0.01)$ between nitrate and rainfall can be attributed to aerated water introduced by rainfall into the wetland that promotes nitrification process and nutrient leaching (Duff et al., 2009; Fennessy et al., 2008; Poulin et al., 2009. The higher concentration of ammonium nitrogen $\left(\mathrm{NH}_{4}{ }^{+}\right)$ compared to other nitrogen species can be attributed to the low oxygen (sometimes anaerobic) conditions prevailing in the wetland that would switch the denitrification process to ammonia production. According to Muthuri and Jones (1997), ammonia form of nitrogen is probably the most important form of nitrogen for plant uptake in wetlands where anaerobic decomposition of litter predominates.

Peak phosphorus concentrations were associated with the $\operatorname{rains}(\mathrm{r}=0.3, \mathrm{p}=0.2)$ and this can be attributed to the enhanced nutrient leaching and litter decomposition during the rainfall when litter gets wetted and submerged. Rainfall and hydroperiods are key factors in nutrient cycling processes of wetlands (Bärlocher and Biddiscombe, 1996; Duff et al., 2009). Thomas et al. (2009) demonstrated how altering hydrology can affect soil processes and ecosystem function in wetlands that are important in nutrient seasonal dynamics. 
The strong negative correlation $(\mathrm{r}=-0.5$, $\mathrm{p}<0.05$ ) between phosphate and $\mathrm{pH}$ may be attributed to the organic species of phosphorus in the wetland, that do not release phosphorus well under acid $\mathrm{pH}$ conditions. At such, $\mathrm{pH}$ free phosphate would exist predominantly as the $\mathrm{H}_{2} \mathrm{PO}_{4}^{-}$species. The Nabugabo ecosystem soil predominant cation is iron compared to other cations that associate with phosphorus. This implies that the dynamics between ferric $\left(\mathrm{Fe}_{3}{ }^{+}\right)$and ferrous $\left(\mathrm{Fe}_{3}{ }^{+}\right)$iron oxides would have some influence on the concentration of phosphorus in water by precipitating it when oxidised and releasing phosphorus when reduced. Low redox conditions therefore favour the release of iron and phosphorus into wetland water (Mitsch and Gossenlink, 2007; Reddy and DeLaune, 2008).

For phosphorus the prevailing $\mathrm{pH}$ and dissolved oxygen (DO) have antagonistic influence with low DO promoting release and low $\mathrm{pH}$ suppressing release, while for nitrate it is the DO that promotes release. $\mathrm{NO}_{3}^{-}$also suppresses phosphate release because of nitrification release of $\mathrm{H}^{+}$into water during process (1) of nitrification (equation 1). Nitrification occurs readily down to $0.3 \mathrm{mg} / \mathrm{l}$ DO (Palmer et al., 2009) a condition available in the Nabugabo wetland (see equations 1 and 2).

The nitrification process:

$$
\begin{aligned}
& 2 \mathrm{NH}_{4}^{+}+3 \mathrm{O}_{2} \leftrightharpoons 4 \mathrm{H}^{+}+2 \mathrm{H}_{2} \mathrm{O}+2 \mathrm{NO}_{2}^{-} \\
& 2 \mathrm{NO}_{2}^{-}+\mathrm{O}_{2} \leftrightharpoons 2 \mathrm{NO}_{3}^{-}
\end{aligned}
$$

Despite the unique ecosystem dominated by ancient leached soils and acidic water, the Nabugabo wetland exhibited nitrogen and phosphorus concentrations that were lower but still comparable to other wetlands in the region (Kipkemboi et al., 2002; Muthuri and Jones, 1997). This means that the Nabugabo wetland internal cycling system is able to maintain a nutrient pool that is comparable to that of other wetlands, and this is important for maintaining a viable ecosystem. Since it is known that the catchment contribution of nutrients and cations is limited or insignificant and that rain water is dilute in the region, the Nabugabo wetland must therefore be a significant source of nutrient and mineral for the ecosystem. This has demonstrated the existence of an efficient internal nutrient cycling in the wetlands with a steady supply of nutrients to the ecosystem. Wetland internal cycling processes is known to maintain a fairly stable pool of nutrients and cations that move between the vegetation, water and soil or peat (Duff et al., 2009; Fennessy et al., 2008; Gupta et al., 2008; Parray et al., 2010; Poulin et al., 2009).

\section{Conclusion}

It has been demonstrated that nitrogen and phosphorus vary significantly with season and that the variation is linked to rainfall and hydroperiod. The wetland keeps a dynamic nutrient pool within as a reservoir for the whole Nabugabo ecosystem. This dynamic reservoir of nutrients and minerals is important for maintaining the Nabugabo ecosystem viability. It is testimony to the notion that the wetland is maintaining the viability of Lake Nabugabo ecosystem by providing the primary nutrients for production. This paper also illustrated that the seasonal hydrological event of flooding and drawdown that alternately operate annually have a big influence on the physico-chemical dynamics of the Nabugabo wetlands like Nabugbo.

\section{ACKNOWLEDGEMENTS}

The author is grateful to the anonymous reviewers who helped to improve the quality of this paper.

\section{REFERENCES}

Agbaire PO, Obi CG. 2009. Seasonal variations of some physic-chemicl properties of River Ethiope water in Abraka, Nigeria. J. Appl. Sci. Eviron. Mang., 13(1): 55-57

APHA. 1992. Standard methods for the examination of water and wastewater. $\left(18^{\text {th }}\right.$ edn). American Public Health Association: Washington.

Bärlocher F, Biddiscombe NR. 1996. Geratology and Decomposition of Typha latifola and Lythrum salicaria in a Freshwater Marsh. Arch. Hydrobiol., 136: 309-325. 
Beadle LC, Lind EM. 1960. Research on the swamps of Uganda. Uganda Journal., Kampala, Uganda, 24: 84-97.

Chapman LJ, Chapman CA. 1996. Wetland Ecotones as Refugia for endangered Fishes. Conserv. Biol., 78: 263-270.

Chapman LJ, Chapman CA, Ogutu-Ohwayo R, Chandler M, Kaufman L, Keiter AE. 1996. Refugia for endangered fishes from an introduced predator in Lake Nabugabo, Uganda. Conserv. Biol., 10: 554-561.

Denny P. 1987. Mineral cycling by wetland plants. A review. Arch. Hydrobiol. Beih., 27: 1-25.

Deuver MJ. 1988. Hydrological processes for Models of Freshwater Wetlands. In Wetland Modelling. Developments in Environmental Modelling, Mitsch WJ, Straskraba M, Jørgensen SE (eds). Elseveir.

Duff JH, Carpenter KD, Snyder DT, Lee KK, Avanzino RJ, Triska FJ. 2009. Phosphorus and nitrogen legacy in a restoration wetland, upper Klamath Lake, Oregon. Wetlands., 29(2): 735-746.

Eaton TT, Yi C. 2009. Hydroperiod and hydraulic loading for treatment potential in urban tidal wetlands. Hdrol Earth Syst. Sci. Discuss., 6: 589-625.

Fennessy MS, Rokosch A, Mack JJ. 2008. Patterns of plant decomposition and nutrient cycling in natural and created wetlands. Wetlands., 28(2): 300-310.

Gupta N, Sharma RC, Tripathi AK.2008. Study of bio-physico-chemical parameters of Mothronwala swamp, Dehradun (Uttarakhand). J. Environ Bio., 29(3): 381-386.

Kaufman LS, Chapman LJ Chapman CA. 1997. Evolution Fast Forward: haplochromine fishes of the Lake Victoria Region. Endeavour., 21: 23-30.

Kipkemboi J, Kamsiime F, Denny P. 2002. The response of Cyperus papyrus (L.) and
Miscanthidium violaceum (K.Schum) Robyns to eutrophication in natural wetlands of Lake Victoria, Uganda. African .J. Aquat. Sci., 27: 11-20.

Mitsch WJ, Gossenlink JG. 2007. Wetlands ( $4^{\text {th }}$ edn). John Wiley and Sons.

Mtui GYS and Nakamura Y. 2006. Physicochemical and microbiological water quality of Lake Sagara in Malagarasi wetlands. J. Engin. Appl. Sci., 1(2): 174-180.

Muthuri FM, Jones MB. 1997. Nutrient distribution in papyrus swamp: Lake Naivasha. Kenya. Aquat. Bot., 56: 35-50.

Okot-Okumu J. 2004. Primary production and decomposition of Loudetia phragmitoides (A. Peter) in the littoral wetland of a small satellite lake (L.Nabugabo, Uganda). Afr. J. Ecol., 42(1): 108-113.

Palmer H, Beutel M, Gebremariam S. 2009. High rates of ammonia removal in experimental oxygen-activated nitrification wetland mesocosms. J. Envir. Engrg., 135(10): 972-979.

Parray SY, Ahmad S, Zubair SM, 2010. Limnological profile of a sub-urban wetland-Chatlam, Kashmir. Int. J. Lakes and Rivers., 3(1): 1-6.

Poulin P, Pelletier E, Koutitonski VG, Neumeier U. 2009. Seasonal fluxes variability or northern salt marshes: examples from the lower St. Lawrence estuary. Wetland Ecol. Man., 17(6): 655673.

Reddy KR, DeLaune RD. 2008. Biogeochemistry of Wetlands: Science Applications. Taylor and Francis Group, LLC.

Thomas CR, Miao S, Sindhoj E. 2009. Environmental factors affecting temporal and spatial patterns of soil redox potential in Florida Everglades wetlands. Wetlands., 4: 1133-1145. 